\title{
Comparative Review of Physicochemical Assessment of Pavana River
}

\author{
${ }^{1}$ Nidhi Jain, ${ }^{2}$ R.K. Shrivastava \\ ${ }^{I}$ Department of Science and Humanity, Genba-Sopanrao Moze Institute of Technology, Pune University, India \\ ${ }^{2}$ P.G.Department of Environmental Science, Government Model Science College, Center of Excellence (NAAC \\ Accredited ('A' Grade, Jabalpur (M.P.), India
}

\begin{abstract}
The study was aimed to review the status of physicochemical characteristics of Pavana river, Pune. Comparative study of data of water quality has been studied from 2005 to 2013 and the physicochemical parameters such as $p H, D O, C O D, B O D$, etc. has been compared. It was found that at many places the water is highly polluted. There was an increase in DO and decrease in COD, BOD contents in the water. For the statistical analysis, values of mean, standard déviations and corrélation were also calculated for the water quality characteristics.
\end{abstract}

Keywords: Pavana river, Pune, Physicochemical, Parameter, Water Quality.

\section{Introduction}

The city of Pune is one of the most important cities of western India in the state of Maharashtra. The city occupies an area of about $1605 \mathrm{Km}^{2}$. It is the 8th largest town in India (population wise), and the second largest in the state of Maharashtra. The population pressure on the city is ever growing. Pune has an abundance of water from the Khadakwasla dam but its intracity distribution is extremely uneven. Some areas get as much as 600 Liters Per Capita Per Day (1pcd) while others get barely 100 lpcd. Ever increasing population, urbanization and modernization are posing problems of sewage, disposal and contamination of surface waters, lakes and rivers $(1,2)$.

The change in water quality also varies due to a change in chemical composition of the underlying sediments and aquifer (3). About one third of the drinking water requirement of the world is obtained from surface sources like rivers, dams, lakes and canals (4). The chemical and physiological process of organism involves utilization of water in some form or the other. Water plays an essential role in several life activities. It has become our prime responsibility to maintain the quality of water from such water samples from rivers and lakes creates an excellent platform to the study of various physicochemical parameters of water namely $\mathrm{pH}$, turbidity, total dissolved solids (TDS), alkalinity and hardness phosphate content, chemical oxygen demand (COD) and sulphate content (5). The physicochemical characteristics of water bodies have been studies by many researchers from time to time (6). The physicochemical properties will also help in the identification of sources of pollution, for conducting further investigation on the eco-biological impacts and also for initiating necessary steps for remedial actions in case of polluted water bodies (7). In India, many researchers have worked on physicochemical and biological characteristics of reservoirs and river (8-15).

\section{Pune City}

Pune city is one of the emerging cities in Maharashtra. More and more people from outside town and cities are migrating into Pune city. Water is the major problem in the fast pace of the city .The major rivers flowing in the city are Mula, Mutha, Pavana, Indrayani, Nira and major lake of Pune city is Katraj lake. Various researches have been conducted on the rivers and lakes in Pune. In the present paper, a comparative study is carried out with statistically analysis to interrelate the problem originated in the past few decades.

\section{Literature Review}

Manohar G, Gavit Mohd et al, 2013 (16) studied in some selected parts of Pavana river like Bopodi and Aundh and concluded the poor water quality in the area (Table 1 and Fig 1). Dissolved oxygen was found very critical at many places of these rivers and at some level it is below the detectable level causing a threat to aquatic life. The hardness of water is quite high. 


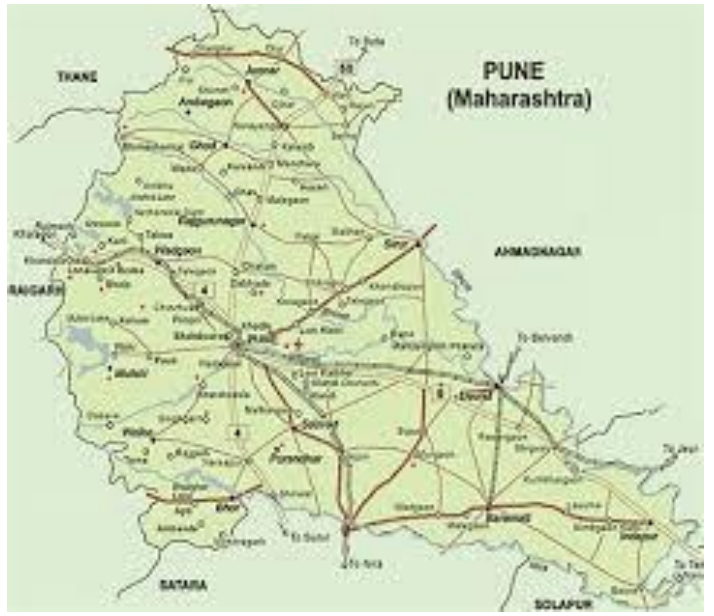

Table 1: Selected locations of Pavana river in 2013 and their statistical analysis

\begin{tabular}{|c|c|c|c|c|c|c|c|c|c|}
\hline \multirow{2}{*}{ Parameters } & \multirow{2}{*}{ Units } & \multicolumn{2}{|c|}{ Pavana } & \multirow{2}{*}{ Mean } & \multirow{2}{*}{ Median } & \multirow{2}{*}{$\begin{array}{l}\text { Standard } \\
\text { Deviation }\end{array}$} & \multirow{2}{*}{ Minimum } & \multirow{2}{*}{ Maximum } & \multirow{2}{*}{$\begin{array}{c}\text { Coefficient of } \\
\text { Variation }\end{array}$} \\
\hline & & Bopodi & Aundh & & & & & & \\
\hline $\mathrm{pH}$ & & 7.6 & 7.2 & 7.4 & 7.4 & 0.3 & 7.2 & 7.6 & 3.8 \\
\hline DO & $\mathrm{mg} / \mathrm{lit}$ & 1.0 & 2.2 & 1.5 & 1.6 & 0.8 & 1.0 & 2.2 & 57.2 \\
\hline BOD & $\mathrm{mg} / \mathrm{lit}$ & 10.3 & 5.0 & 7.2 & 7.7 & 3.8 & 5.0 & 10.3 & 52.4 \\
\hline COD & $\mathrm{mg} / \mathrm{lit}$ & 53.1 & 15.4 & 28.5 & 34.2 & 26.7 & 15.4 & 53.1 & 93.4 \\
\hline Chloride & $\mathrm{mg} / \mathrm{lit}$ & 9.8 & 7.6 & 8.6 & 8.7 & 1.6 & 7.6 & 9.8 & 18.0 \\
\hline Sulphate & $\mathrm{mg} / \mathrm{lit}$ & 13.9 & 7.2 & 10.0 & 10.6 & 4.7 & 7.2 & 13.9 & 47.4 \\
\hline Hardness & $\mathrm{mg} / \mathrm{lit}$ & 351.0 & 276.0 & 311.2 & 313.5 & 53.0 & 276.0 & 351.0 & 17.0 \\
\hline Calcium level & $\mathrm{mg} / \mathrm{lit}$ & 179.3 & 32.8 & 76.7 & 106.1 & 103.6 & 32.8 & 179.3 & 135.1 \\
\hline Magnesium & $\mathrm{mg} / \mathrm{lit}$ & 246.6 & 51.6 & 112.8 & 149.1 & 137.9 & 51.6 & 246.6 & 122.2 \\
\hline Total Alkalinity & $\mathrm{mg} / \mathrm{lit}$ & 86.6 & 65.6 & 75.4 & 76.1 & 14.8 & 65.6 & 86.6 & 19.7 \\
\hline \begin{tabular}{|l|} 
Nitrate \\
\end{tabular} & $\mathrm{mg} / \mathrm{lit}$ & 20.0 & 5.1 & 10.1 & 12.6 & 10.5 & 5.1 & 20.0 & 104.3 \\
\hline TDS & $\mathrm{mg} / \mathrm{lit}$ & 8.3 & 6.4 & 7.3 & 7.4 & 1.3 & 6.4 & 8.3 & 18.4 \\
\hline Phospahte & $\mathrm{mg} / \mathrm{lit}$ & 2.8 & 0.8 & 1.5 & 1.8 & 1.4 & 0.8 & 2.8 & 94.5 \\
\hline
\end{tabular}

Figure 1: Comparison of various parameters of Pavana river in 2013.

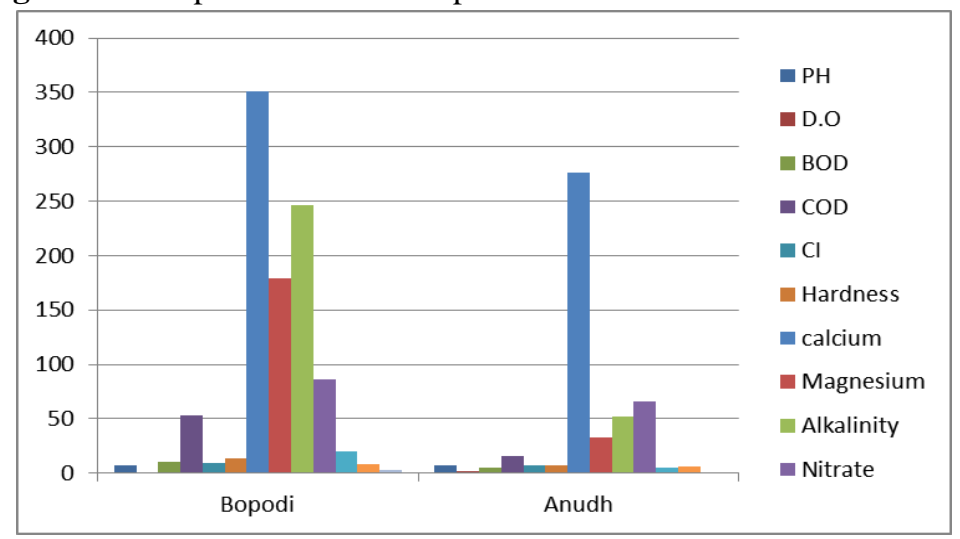

Mane A.V., Pardeshi R.G. et al, 2013 (17) have studied level of contaminants of surface water, ground water and sediment analysis of selected locations of Pavana river of Pimpri-Chinchwad area of Pune district (Table 2 and Fig 2). Researchers assess the water quality including pH, EC, TDS, DO, COD, BOD, Alkalinity and free $\mathrm{CO}_{2}$, hardness, phosphate $\left(\mathrm{PO}_{4}\right)$, sediments analysis, heavy metal analysis in water, as well as in sediments samples, collected from the four sites of Pavana river, Pimpri-Chinchavad of Pune district. The study was carried out in the month of January 2012, and distance between each site was about $2 \mathrm{~km}$. The sites 3 and 4 were observed to be polluted because of industries around and their discharges. It was also observed that the natural quality of water resources is getting deteriorated at faster rate. Ground water of this area showed higher 
values of hardness content as compared to surface water range (58 to $111.2 \mathrm{mg} / \mathrm{l})$. The higher value of TDS $(195.6 \mathrm{mg} / \mathrm{l})$ in one area of water and in other site $65.12 \mathrm{mg} / \mathrm{l}$. COD was observed by value of $120 \mathrm{mg} / \mathrm{l}$ at surface water at one site, $33.8 \mathrm{mg} / \mathrm{l}$ at other site.

Table 2 : Selected locations of Pavana river in 2012 and their statistical analysis

\begin{tabular}{|c|c|c|c|c|c|c|c|c|c|c|c|}
\hline \multirow[b]{2}{*}{ Parameters } & \multirow[b]{2}{*}{ Units } & \multicolumn{3}{|c|}{ Pavana } & \multirow[b]{2}{*}{$\begin{array}{l}\text { Kalewadi } \\
\text { Phata }\end{array}$} & \multirow[b]{2}{*}{ Mean } & \multirow[b]{2}{*}{ Median } & \multirow{2}{*}{$\begin{array}{l}\text { Standard } \\
\text { Deviation }\end{array}$} & \multirow[b]{2}{*}{ Minimum } & \multirow[b]{2}{*}{ Maximum } & \multirow{2}{*}{$\begin{array}{l}\text { Coefficient } \\
\text { of Variation }\end{array}$} \\
\hline & & Kivalegoan & $\begin{array}{c}\text { Ravet Punavale } \\
\text { Bridge }\end{array}$ & Chinchvadgaon & & & & & & & \\
\hline $\mathrm{PH}$ & & 8.1 & 7.9 & 7.7 & 7.4 & 7.8 & 7.8 & 0.3 & 7.4 & 8.1 & 3.9 \\
\hline DO & $\mathrm{mg} / \mathrm{lit}$ & 4.8 & 3.2 & 5.2 & 1.6 & 3.4 & 4.0 & 1.7 & 7.4 & 5.2 & 49.0 \\
\hline$B O D$ & $\mathrm{mg} / \mathrm{lit}$ & 33.8 & 46.2 & 51.2 & 35.1 & 40.9 & 40.7 & 8.5 & 33.8 & 51.2 & 20.8 \\
\hline$C O D$ & $\mathrm{mg} / \mathrm{lit}$ & 107.0 & 105.0 & 114.0 & 120.0 & 111.3 & 110.5 & 6.9 & 33.8 & 120.0 & 6.2 \\
\hline Hardness & $\mathrm{mg} / \mathrm{lit}$ & 58.0 & 72.6 & 86.0 & 111.2 & 79.7 & 79.3 & 22.6 & 58.0 & 111.2 & 28.4 \\
\hline EC & $\mu \mathrm{S}$ & 130.4 & 164.1 & 249.3 & 408.1 & 216.0 & 206.7 & 124.0 & 58.0 & 408.1 & 57.4 \\
\hline Alkalinity & $\mathrm{mg} / \mathrm{lit}$ & 72.0 & 64.0 & 188.0 & 216.0 & 117.0 & 130.0 & 78.3 & 64.0 & 216.0 & 66.9 \\
\hline TDS & $\mathrm{mg} / \mathrm{lit}$ & 65.1 & 82.1 & 124.3 & 195.6 & 106.8 & 103.2 & 58.1 & 64.0 & 195.6 & 54.4 \\
\hline Phosphate & $\mathrm{mg} / \mathrm{lit}$ & 17.9 & 20.8 & 7.4 & 10.5 & 13.0 & 14.2 & 6.3 & 7.4 & 20.8 & 48.1 \\
\hline
\end{tabular}

Figure 2: Comparison of various parameters of Pavana river in 2012

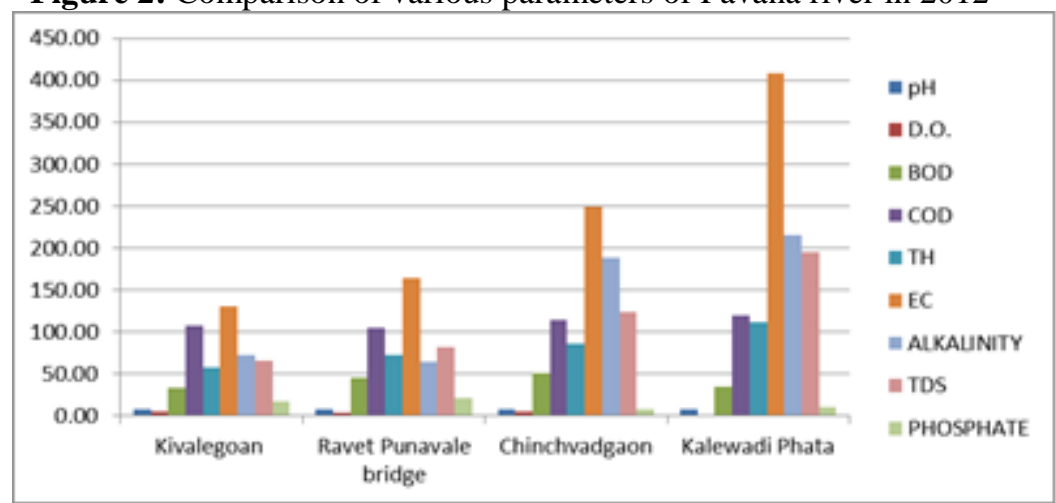

D.G. Kanase et al 2005 (18) studied the physicochemical characteristics of major river in Pune city. They studied and analyzed the Pavana river along with Mula and Mutha river (Table 3 and Fig 3). The analysis was carried out for the parameters namely $\mathrm{pH}$, Acidity, Alkalinity, Total Hardness, Calcium, Magnesium, Chloride, Nitrate, Sulphate and Phosphate. The data obtained by the analysis revealed that the COD is beyond the limit in Pavana river. The $\mathrm{pH}$ is between 7.5 \& 8.6, DO, Chloride, Nitrate, Sulphate and Phosphate are within the desirable limits.

Table 3: Selected locations of Pavana river in 2005 and their statistical analysis

\begin{tabular}{|c|c|c|c|c|c|c|c|c|c|}
\hline \multirow{2}{*}{ Parameters } & \multirow{2}{*}{ Units } & \multicolumn{2}{|c|}{ Pavana } & \multirow{2}{*}{ Mean } & \multirow{2}{*}{ Median } & \multirow{2}{*}{$\begin{array}{l}\text { Standard } \\
\text { Deviation }\end{array}$} & \multirow{2}{*}{ Minimum } & \multirow{2}{*}{ Maximum } & \multirow{2}{*}{$\begin{array}{c}\text { Coefficient of } \\
\text { Variation }\end{array}$} \\
\hline & & Sanghvi & Chinchwad & & & & & & \\
\hline $\mathrm{PH}$ & & 7.5 & 8.6 & 8.0 & 8.1 & 0.8 & 7.5 & 8.6 & 9.7 \\
\hline $\mathrm{DO}$ & $\mathrm{mg} / \mathrm{lit}$ & 3.5 & 5.2 & 4.2 & 4.3 & 1.2 & 3.5 & 5.2 & 27.6 \\
\hline $\mathrm{BOD}$ & $\mathrm{mg} / \mathrm{lit}$ & 101.0 & 46.0 & 68.2 & 73.5 & 38.9 & 46.0 & 101.0 & 57.1 \\
\hline COD & $\mathrm{mg} / \mathrm{lit}$ & 543.0 & 467.0 & 503.6 & 505.0 & 53.7 & 467.0 & 543.0 & 10.7 \\
\hline Calcium level & $\mathrm{mg} / \mathrm{lit}$ & 26.9 & 18.0 & 22.0 & 22.5 & 6.3 & 18.0 & 26.9 & 28.5 \\
\hline \begin{tabular}{|l|} 
Magnesium \\
\end{tabular} & $\mathrm{mg} / \mathrm{lit}$ & 8.6 & 6.3 & 7.4 & 7.4 & 1.6 & 6.3 & 8.6 & 21.6 \\
\hline Nitrate & $\mathrm{mg} / \mathrm{lit}$ & 17.4 & 17.1 & 17.2 & 17.3 & 0.2 & 17.1 & 17.4 & 1.2 \\
\hline Phosphate & $\mathrm{mg} / \mathrm{lit}$ & 1.8 & 2.6 & 2.2 & 2.2 & 0.6 & 1.8 & 2.6 & 26.1 \\
\hline
\end{tabular}


Figure 3: Comparison of various parameters of Pavana river in 2005

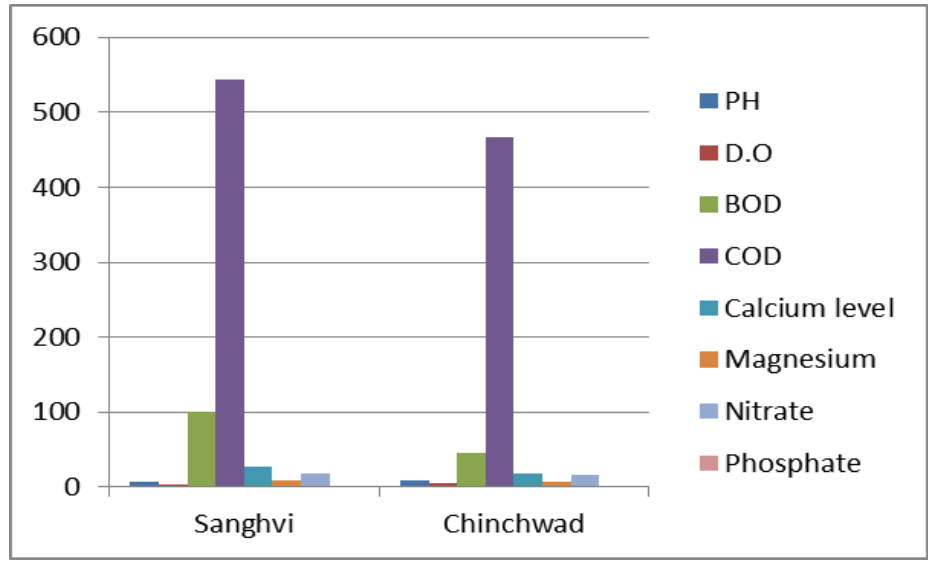

Table 4: Consolidated data of Pavana river from 2005 to 2013

\begin{tabular}{|c|c|c|c|c|c|c|c|c|c|}
\hline Parameters & & Sanghvi & Chinchwad & Kivalegoan & $\begin{array}{c}\text { Ravet Punavale } \\
\text { Bridge }\end{array}$ & Chinchvadgaon & $\begin{array}{c}\text { Kalewadi } \\
\text { Phata }\end{array}$ & Bopodi & Aundh \\
\hline & Year --> & 2005 & 2005 & 2012 & 2012 & 2012 & 2012 & 2013 & 2013 \\
\hline $\mathrm{pH}$ & & 7.5 & 8.6 & 8.1 & 7.9 & 7.7 & 7.4 & 7.6 & 7.2 \\
\hline DO & $\mathrm{mg} / \mathrm{lit}$ & 3.5 & 5.2 & 4.8 & 3.2 & 5.2 & 1.6 & 1.0 & 2.2 \\
\hline BOD & $\mathrm{mg} / \mathrm{lit}$ & 101.0 & 46.0 & 33.8 & 46.2 & 51.2 & 35.1 & 10.3 & 5.0 \\
\hline COD & $\mathrm{mg} / \mathrm{lit}$ & 543.0 & 467.0 & 107.0 & 105.0 & 114.0 & 120.0 & 53.1 & 15.4 \\
\hline Hardness & $\mathrm{mg} / \mathrm{lit}$ & & & 58.0 & 72.6 & 86.0 & 111.2 & 351.0 & 276.0 \\
\hline EC & $\mathrm{umg} / \mathrm{cm}$ & & & 130.4 & 164.1 & 249.3 & 408.1 & & \\
\hline Alkalinity & $\mathrm{mg} / \mathrm{lit}$ & & & 72.0 & 64.0 & 188.0 & 216.0 & 86.6 & 65.6 \\
\hline TDS & $\mathrm{mg} / \mathrm{lit}$ & & & 65.1 & 82.1 & 124.3 & 195.6 & 8.3 & 6.4 \\
\hline Phosphate & $\mathrm{mg} / \mathrm{lit}$ & & & 17.9 & 20.8 & 7.4 & 10.5 & 2.8 & 0.8 \\
\hline
\end{tabular}

pH: Statistical analysis of Pavana water data has been performed and concluded that $\mathrm{pH}$ value 2013 is 7.2 (min) and $7.6(\max )$ and in 2012 it was $7.4(\mathrm{~min})$ and $8.1(\max )$ and in 2005 is $7.5(\min )$ and $8.6(\max )($ Fig 4). The $\mathrm{pH}$ value seems towards more alkaline side. Generally, the obtained $\mathrm{pH}$ values fall within the World Health Organization standard of 7.0 to 8.5 and water quality ranges 6.5 to 8.5 for drinking water and water meant for full contact recreation, respectively. (DWAF, 1996)

Figure 4:. pH Data

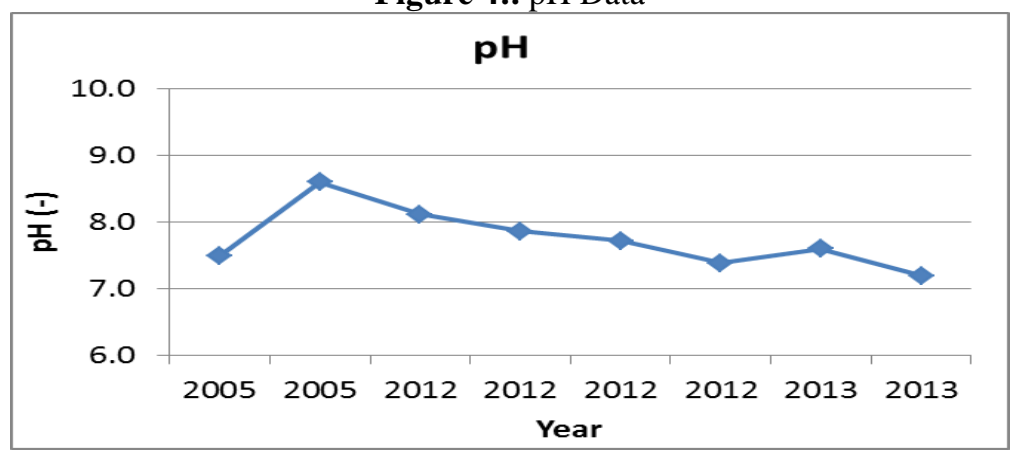

Dissolved Oxygen (DO): The graphical representation of the graph of D.O. shows that in 2005, it was ranging from $3.5 \mathrm{mg} / \mathrm{l}(\mathrm{min})$ to $5.2 \mathrm{mg} / \mathrm{l}(\max )$ and 2013 value was $1.0 \mathrm{mg} / \mathrm{l}(\mathrm{min})$ and $2.2 \mathrm{mg} / \mathrm{l}(\mathrm{max}))($ Fig5).The value of D.O. has decreased from 2005 to 2013. Due to decrease in the value of D.O. there is a major decrease in aquatic life in the river. Almost all plants and animals need dissolved oxygen for respiration. A good quality of water should have a solubility of oxygen 7.0 to $7.6 \mathrm{mg} / \mathrm{l}$ at $30^{\circ} \mathrm{C}$ respectively (19). 


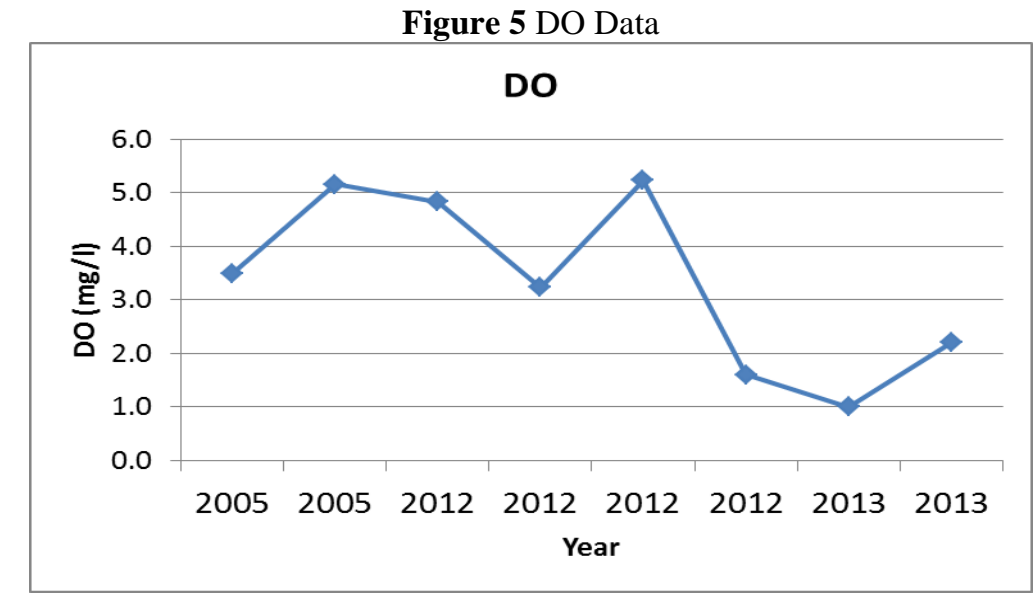

Biochemical Oxygen Demand (BOD): The value of BOD in 2005 sample is $101 \mathrm{mg} / \mathrm{l}$ (max) and $\mathrm{min} 46 \mathrm{mg} / \mathrm{l}$ ( $\mathrm{min}$ ) and in 2012 to 2013 it becomes $5 \mathrm{mg} / \mathrm{l}(\mathrm{min})$ and $10.33 \mathrm{mg} / \mathrm{l}(\mathrm{max})$, this indicates that there is a decrease value of BOD from 2005 to 2013 (Fig 6). When BOD is high, it means there is lot of organic contaminants in the water and the microbes are consuming organic contaminants. They use up the oxygen while doing this so when BOD is high, there is the possibility in decrease in D.O. Organic compounds or oxidisable inorganic substances.

Figure 6 BOD Data

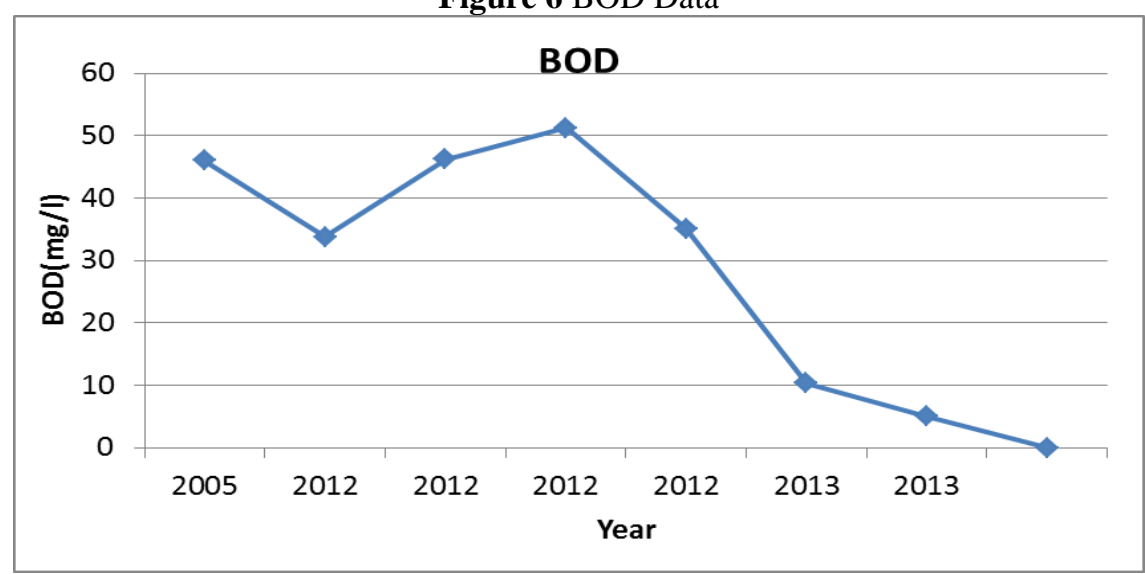

Chemical Oxygen Demand (COD): The maximum permissible limit for COD is $10 \mathrm{mg} / \mathrm{l}$ for drinking water (20). COD or Chemical Oxygen Demand is the total measurement of all chemical (organic and inorganics) in the water (waste water) and the probably the most common test for estimation industrial waste water strength. This test essentially measure the chemical oxidation of the waste water by a strong oxidizing agent in an acid solution.The value for the COD test is always greater than the BOD value for the same waste. When we see the graph (Fig 7) there was a vast decrease in COD value from 2005 to 2013 in Pavana river. Decrease is due to the type of area since Chindwad is the industrial area but Aundh is residential area.

Hardness: The hardness value has increased from $111.2 \mathrm{mg} / \mathrm{l}(\max )$ to 351.0 (max). The total hardness of water basically depends upon the calcium and magnesium content of water. The calcium is one of the alkaline earth metals not known to produce any hazardous effect on human health.

TDS: TDS value is high in 2012 and 2013 from $6.4(\mathrm{~min})$ to $65.1(\max )$ and $8.3(\mathrm{~min})$ to $195.6(\mathrm{max}) \mathrm{mg} / \mathrm{l}$. The excess dissolved solid generally affects the potability of water. This variation is because of pollutants which come along with the effluents of the nearby industries and other inlets. 


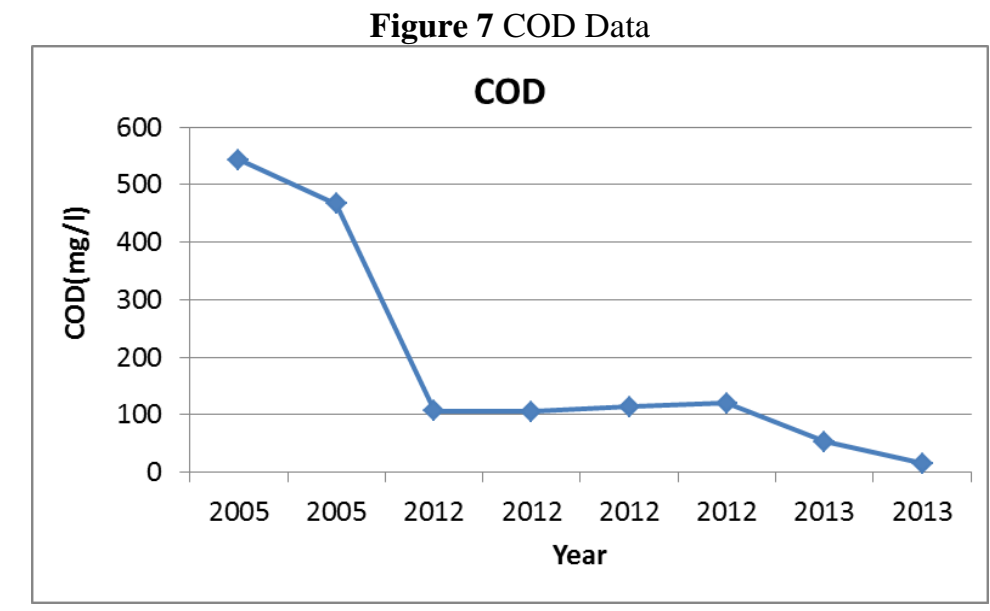

Phosphate: Phosphate level is the most critical and limiting factor in the maintenance of water fertility. Agriculture runoff containing nutrients fertilizers contributed to the increase in phosphate in an ecosystem (21, 22). Phosphate value in 2012 is $7.38 \mathrm{mg} / \mathrm{l}(\mathrm{min})$ and $21 \mathrm{mg} / \mathrm{l}(\max )$ and in $2013,0.8 \mathrm{mg} / \mathrm{l}(\mathrm{min})$ and $2.0 \mathrm{mg} / \mathrm{l}$ (max).

\section{Conclusion}

The present study shows that the Pavana river is carrying industrial and domestic waste from Chinchwad Corporation. At many places, the water is highly polluted. Aundh area side is less polluted because of the residential colony. The polluted areas with heavy influx of organic and innumerable industrial waste has drastically reduced the biodiversity in city area and downstream of river. From 2005 to 2013, there is large variation in waste quality

There is a decrease in COD, BOD and phosphate contents in the water. Further studies are needed to improve the water quality and lead remedial measure. There is a need to have proper collection and treatment of waste.

\section{References}

[1]. Mehta Dinesh, Raghupati, Usha, Sharma, Rajesh (1994), Squalor that need not to be, The Hindu Survey of Environment, Page 11.

[2]. Mehta, Dinesh (1995) future proteins-The Hindu Survey ofEenvironment, Page 65

[3]. A. Jameel, (2000), Indian Journal Enviro. Prot. 44(2), Page108-112.

[4]. S.B.Jannalagada; and G.Mhere (2001).Water Res, 35, Page 2371-2376.

[5]. Eswarla Sedamkar and Angadi,S.B.,(2003) Physicochemical parameters of two fresh water bodies of Gulberga, India with two special reference to phytoplankton. Pollution Research, 22(3), Page 411-422.

[6]. Mathew Kashy and T. Vasudwan Nayer (1999), Water quality aspects of rivers Pambo, Pollution Reasearch 18 (4), Page 501-510.

[7]. U.K. Ekwenye; CA Oji, (2008), Environ. Ecol, 26, Page 543-545.

[8]. D.N. Saksena, R.K. Garge and RJ Rao (2008), Journal of Environmental Biology, 29 (5), Page 710.

[9]. R.K. Trivedy; and P K Goel, (1986) Environmental Publication, Karad, Maharashtra.

[10]. G.R. Jakhar; S C Bhargava; and R K Sinha, (1990), Geobiology.

[11]. S. Rao,( 1993) Fresh Water Molluscs of Indian Recent Advances in Fresh Water, Anmol Publications Pvt. Ltd. New Delhi, Page. 4752 .

[12]. S. Patil; and J.M. Patwari (2003), J. Aquatic Biology, Vol. 18(2), Page 85-86

[13]. A. Shayestehfar; M. Soleimani; S.N. Mousavi; and F. Shirazi, (2008) Iran Journal of Environmental Biology, 29(5), Page 715-720.

[14]. R.N. Barik; and R.K. Patel, (2004), Indian Journal of Environmental Protection, 24 (03), Page 161-166.

[15]. R.K. Gaur; A. A. Khan; A Alam; and Md. A. Alam, (1997), Indian Journal Of Environmental Protection 20(3), Page 165-17.

[16]. Manohar G. Gavit, Mohd. Shahnawaz, Manish K. Sangale, Halimabi A. Kureshi and Avinash Bade, (2013), International Journal of Current Research 5(02), Page 232-235.

[17]. Mane A.V., Pardeshi R.G. etal (2013), Journal of Chemical and Pharmaceutical Research 5(8), Page 91-102.

[18]. D.G.Kanase, S.D.Jadhav, R.W.Jawale, M.S.Kadam, A study on some physicochemical characteristics of flowing water of major river in Pune city.

[19]. A. Kudesia De, (1985). The saga of the Damodar Rivers, Journal of Indian Chemical Society 62, Page 1038.

[20]. Usharani K, Umarani K,Ayyasamy Pm, Shanthi K, Lakshmanaperumalsamy P (2010), Physicochemical and bacteriological characteristics of Noyyal river and ground water quality of Perur, India, Journal of Applied Science Environ Manage 14(2), Page 2935.

[21]. Bath K.S. and Jatinderpal Singh (1998), Limnology of polluted urban pond, Environment and Ecology 16(4), Page 776-779.

[22]. Desai P.V., Godse S.J. and Halkar S.G. (1995), Physicochemical characteristics of Khandepar river, Goa, India, Journal of Pollution Research,14 (4), Page 447-454. 